University of South Florida

DIGITAL COMMONS

Digital Commons @ University of

@ UNIVERSITY OF SOUTH FLORIDA

South Florida

The Inside, Outside, and Upside Downs of

Children's Literature: From Poets and Pop-ups

to Princesses and Porridge

Teaching and Learning

$1-1-2016$

\title{
Chapter 11: Past Presidents and Evading Inventors: Not Your Grandmother's Information Books
}

Jenifer Jasinski Schneider

University of South Florida, jschneid@usf.edu

Follow this and additional works at: https://digitalcommons.usf.edu/childrens_lit_textbook

Part of the Education Commons

\section{Recommended Citation}

Schneider, Jenifer Jasinski, (2016). Past Presidents and Evading Inventors: Not Your Grandmother's Information Books. In The Inside, Outside, and Upside Downs of Children's Literature: From Poets and Pop-ups to Princesses and Porridge (p. 301-323). http://dx.doi.org/10.5038/9780977674411.ch11

This Book Chapter is brought to you for free and open access by the Teaching and Learning at Digital Commons @ University of South Florida. It has been accepted for inclusion in The Inside, Outside, and Upside Downs of Children's Literature: From Poets and Pop-ups to Princesses and Porridge by an authorized administrator of Digital Commons@ University of South Florida. For more information, please contact digitalcommons@usf.edu. 


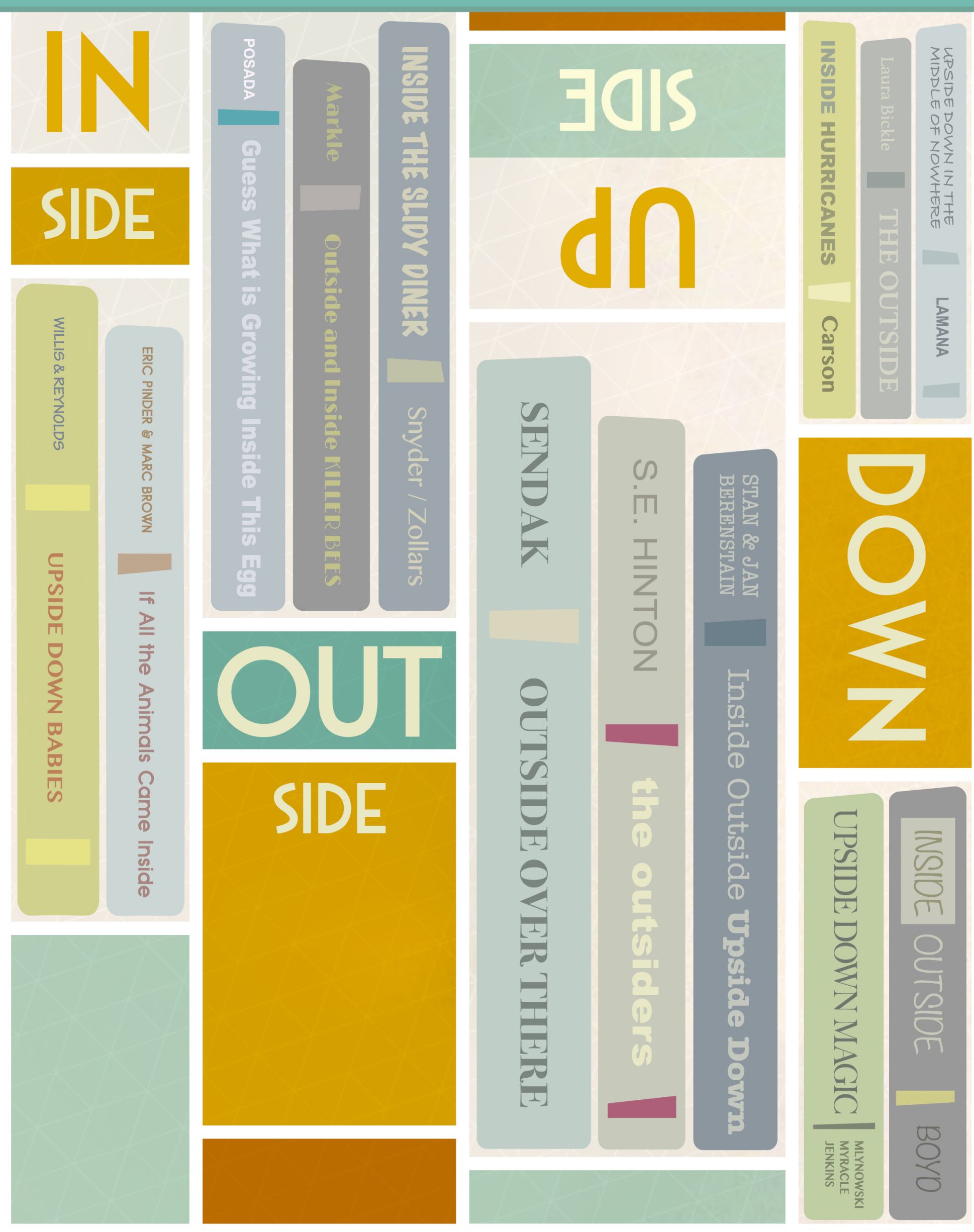

\section{THE INSIDE, OUTSIDE, AND UPSIDE DOWIS From Poets and Pop-ups to OF CHILDREN'S LITERATURE Princesses and Porridge}




\section{The Inside, Outside, and Upside Downs of Children's Literature: From Poets and Pop-ups to Princesses and Porridge}

Jenifer Jasinski Schneider, Ph.D. 
Copyright

Published by The University of South Florida Library, 4202 E. Fowler Avenue, Tampa, FL 33620.

Copyright (C2016 by Jenifer Jasinski Schneider. All rights reserved.

\section{(c) $(1) \odot$}

This work is licensed under a Creative Commons Attribution-NonCommercial-NoDerivatives 4.0 International License.

Author and Editor in Chief: Jenifer Jasinski Schneider

Editorial Director: Monica Metz-Wiseman

Media Project Manager and Producer: Christine Brown

Video Producers and Editors: Jared Brown, Jason Su, Ian Crenshaw, Jessica Brennen,

Diana Trueman, Jeremy Willis

Art Director: Stephanie Rivera

Illustrators and Multimedia Designers: William Tillis and Elise Michal

Copyright Coordinator: LeEtta M. Schmidt

Open-Access Editor: Jason Boczar

Editorial Manager: Carol Ann Borchert

Editorial Project Manager: Chelsea Johnston

Cover image book credits:

Upside Down Babies by Jeanne Willis and Adrian Reynolds (C)2013 Andersen Press; If All the Animals

Came Inside by Eric Pinder and Marc Tolon Brown (C)2012 Little, Brown and Company; Guess What Is Growing Inside This Egg by Mia Posada (C2007 Millbrook Press; Outside and Inside Killer Bees by Sandra Markle (C)2004 Walker \& Co.; Inside the Slidy Diner by Laurel Snyder and Jaime Zollars (C)2008 Tricycle Press; Outside Over There by Maurice Sendak (C)1989 HarperCollins; The Outsiders by S.E. Hinton, original cover art by Robert Hunt (C1967 Viking Press. Mass Market edition (C1997 Speak; Inside Outside Upside Down by Stan and Jan Berenstain (C1968 Random House; Upside Down Magic by Sarah Mlynowski, Lauren Myracle, and Emily Jenkins (C)2015 Scholastic Press; Inside Outside by Lizi Boyd (C)2013 Chronicle Books; Inside Hurricanes by Mary Kay Carson (C)2010 Sterling; The Outside by Lauren Bickle (C)2013 Houghton Mifflin Harcourt; Upside Down in the Middle of Nowhere by Julie T.

Lamana (C)2014 Chronicle Books.

Library of Congress Cataloging-in-Publication Data

Schneider, Jenifer Jasinski, 1968-

The Inside, Outside, and Upside Downs of Children's Literature: From Poets and Pop-ups to Princesses and Porridge / Jenifer Jasinski Schneider.

ISBN- 978-0-9776744-1-1 eBook

ISBN- 978-0-9776744-2-8 print

The Internet addresses listed in the text were accurate at the time of publication. 


\section{TEXTUAL TENDENCEES AND OPEN AND CLOSE READINGS}

\section{SECTION 3}




\section{CHAPTER PAST PRESIDENTS AND EVADING INVENTORS: NOT YOUR GRANDMOTHER'S INFORMATION BOOKS \\ 11 (PORTRAYING PEOPLE, ARGUING POSITIONS, AND PRESENTING DISCIPLINARY CONTENT]}

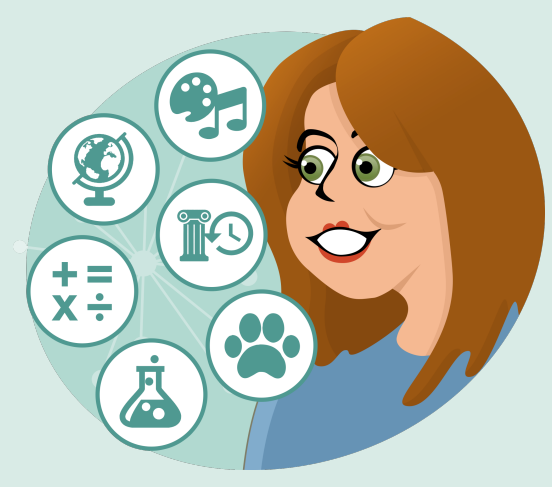

Unlike the poet or the storyteller, the nonfiction writer is often viewed as less of an artist and more of a technician. The poet is a "responsible commentator" (Smith, 2010), sending persuasive and descriptive messages that are personal, political, or playful. The fiction writer is a storyteller, using description and narration to build imagined worlds that are realistic and fantastic. In contrast, the nonfiction writer is instructive, logical, and factual; using text structures to build concepts, present information, and clarify concepts. Where's the art in that? Well, there's plenty.

Poorly written information books are boring and overly simplified or filled with lifeless chronologies of events and factual statements. They are often written by experts with little knowledge of youth or written by no-name technical writers with stock knowledge of content. Expertise is essential in the creation of nonfiction texts, and so is strong writingafter all, we are talking about the creation of books. Contemporary information books are cleverly written, they feature amazing photographs and illustrations, and they focus on important material that interests and challenges readers.

The purpose of this chapter is to explore modern approaches to informational writing for children, which may include argumentative, descriptive, and narrative elements as well. In doing so, I dispel some myths about nonfiction texts as boring, bland, and basic. I identify how nonfiction literature can be used to enhance learning across disciplinary areas. I also share examples of the literature that reflect current trends.

The iNK Think Tank (http://inkthinktank.com) is focused on creating interesting nonfiction for kids. The authors and illustrators who are members of this community write blogs, visit schools, and create content to share in the Nonfiction Minute (http://www.nonfictionminute.com).

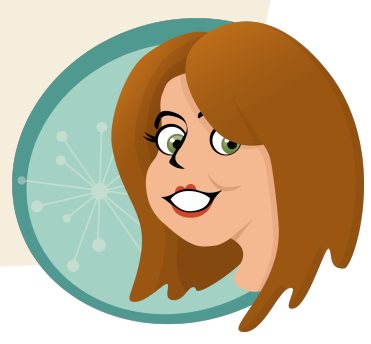




\section{The Quest for Information}

Nonfiction books clarify content and reveal the subject through accuracy, documentation, organization, visual material and book design. Such books display respect for children's understanding, abilities, and aesthetic appreciation. They also appeal to adults.

\section{Relevant Topics and Professional Interests}

Think about your college major, your current professional position, or your future aspirations. Are you in health sciences, social work, business, art, engineering, hospitality? What are your professional interests?

Find two children's information books that relate to your profession. Yes, that's right-a children's book. The content of nonfiction children's literature spans all disciplines.

Find award-winning nonfiction books categorized by discipline:

History: http://www.ncte.org/library/NCTEFiles/About/Awards/OPBooks-Historical.pdf Science: http://www.ncte.org/library/NCTEFiles/About/Awards/OPBooks-Science.pdf Biography: http://www.ncte.org/library/NCTEFiles/About/Awards/OPBooksBiographical.pdf

For example, if your career is in English, language, or linguistics maybe these books are right for you?

- The Right Word: Roget and His Thesaurus written by Jen Bryant and illustrated by Melissa Sweet, 2014, New York, NY: Eerdmans.

- Sequoyah: The Cherokee Man Who Gave his People Writing by James Rumford and translated by Anna Sixkiller Huckaby, 2004, New York, NY: HMH Books for Young Readers (Figure 11.1).

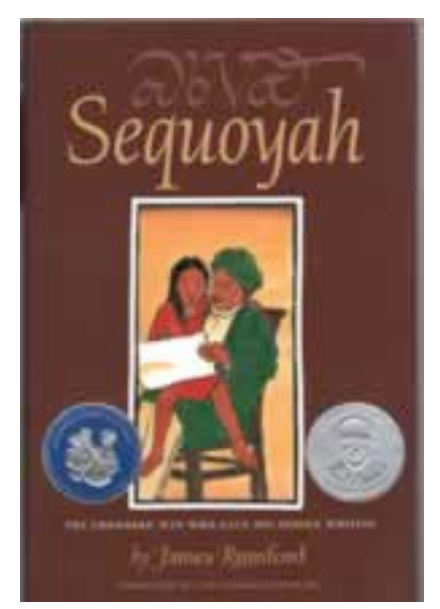

Figure 11.1

If you are interested in languages, Sequoyah provides a glimpse into Cherokee history. Sequoyah: The Cherokee Man Who Gave his People Writing by James Rumford and translated by Anna Sixkiller Huckaby, 2004, New York, NY: HMH Books for Young Readers. Cover image copyright 2004 by Anna Sixkiller Huckaby. 
- If your career is in fashion, marketing, art direction, or performance, check out the following:

- Balloons Over Broadway written and illustrated by Melissa Sweet, 2011, New York, NY: HMH Books for Young Readers.

- My Story, My Dance: Robert Battle's Journey to Alvin Ailey by Lesa Cline-Ransome, illustrated by James E. Ransome, 2015, New York, NY: Simon \& Schuster (Figure 11.2).

- If your career aspirations are in business, politics, or economics, look for books on related topics.

- Growing Money: A Complete Investing Guide for Kids written by Gail Karlitz and Debbie Honig, 2010, New York, NY: Price Stern Sloan.

- So You Want to be President written by Judith St. George and illustrated by David Small, 2004/2012, New York, NY: Philomel (Figure 11.3).

- Or, do you just love numbers and math? Read about number people and math problems.

- Money Madness by David A. Adler and illustrated by Edward Miller, 2010, New York, NY: Holiday House.

- Mystery Math: A First Book of Algebra written by David A. Adler and illustrated by Edward Miller, 2011, New York, NY: Holiday House. (Figure 11.4).

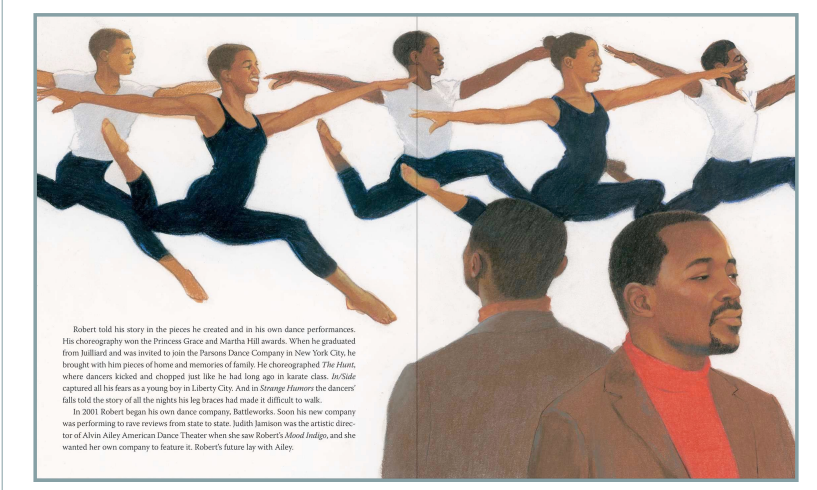

Figure 11.2

Read about Robert Battle in My Story, My Dance: Robert Battle's Journey to Alvin Ailey by Lesa Cline-Ransome, illustrated by James E. Ransome, 2015, New York, NY: Simon \& Schuster. Illustration copyright 2015 by James E. Ransome.

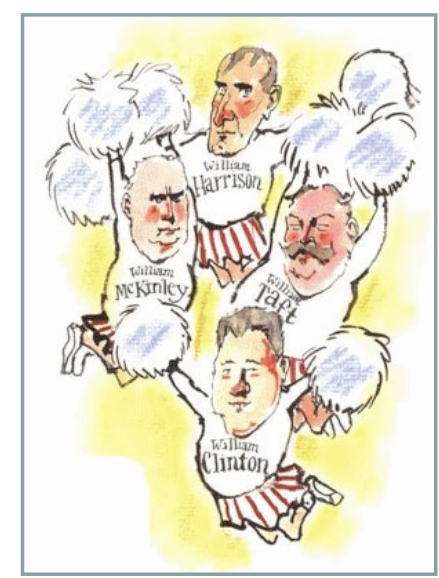

Figure 11.3

If you like quirky facts about the Presidency and the Presidents of the US, this book is for you. So You Want to be President written by Judith St. George and illustrated by David Small, 2004/2012, New York, NY: Philomel. Illustration copyright $2004 / 2012$ by David Small.

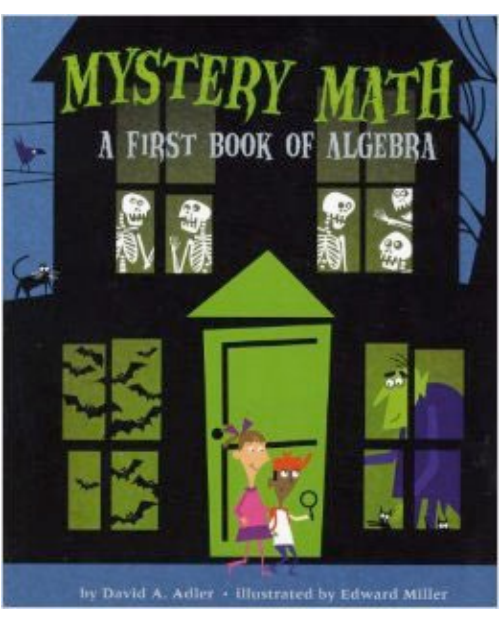

Figure 11.4

Part story, part mystery, part math. This book integrates mathematical thinking with narrative. Mystery Math: A First Book of Algebra written by David A. Adler and illustrated by Edward Miller, 2011, New York, NY: Holiday House. Cover art copyright 2011 by Edward Miller. 
- Focused on law, civil rights, and cultures? Read about others like you.

- Funny Bones: Posada and His Day of the Dead Calaveras by Duncan Tonatiuh, 2015, New York, NY: Harry N. Abrams (Figure 11.5).

- Drowned City: Hurricane Katrina \& New Orleans written by Don Brown, 2015, New York, NY: HMH Books for Young Readers.

- Perhaps you are an historian or your career is in the military.

- Bomb: The Race to Build-and Steal-the World's Most Dangerous Weapon written by Steve Sheinkin, 2012, New York, NY: Flash Point (Figure 11.6).

- Hitler Youth: Growing Up in Hitler's Shadow written by Susan Campbell Bartoletti, 2005, New York, NY: Scholastic.

- Are you an environmentalist or scientist? Look for books that address your issues and concerns.

- The Elephant Scientist by Caitlin O'Connell and

Donna M. Jackson/photographs by Caitlin O'Connell and Timothy Rodwell, 2011, New York, NY: HMH Books for Young Readers.

- Kakapo Rescue: Saving the World's Strangest Parrot, written by Sy Montgomery, photographs by Nic Bishop, 2010, New York, NY: Houghton Mifflin Books for Children (Figure 11.7).

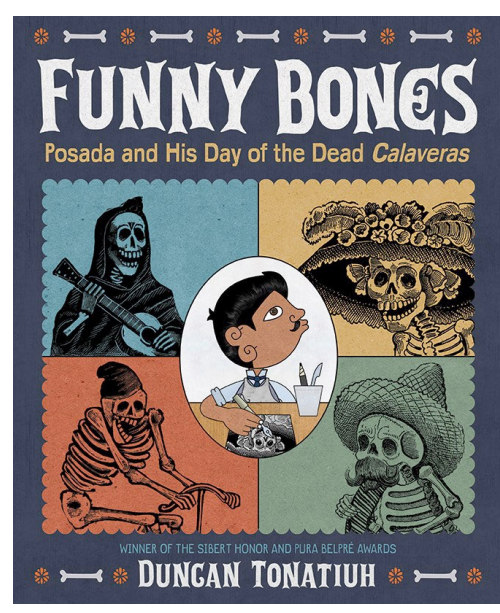

Figure 11.5

Learn about the Day of the Dead. Funny Bones: Posada and His Day of the Dead Calaveras by Duncan Tonatiuh, 2015, New York, NY: Harry N. Abrams. Copyright 2015 by Duncan Tonatiuh.

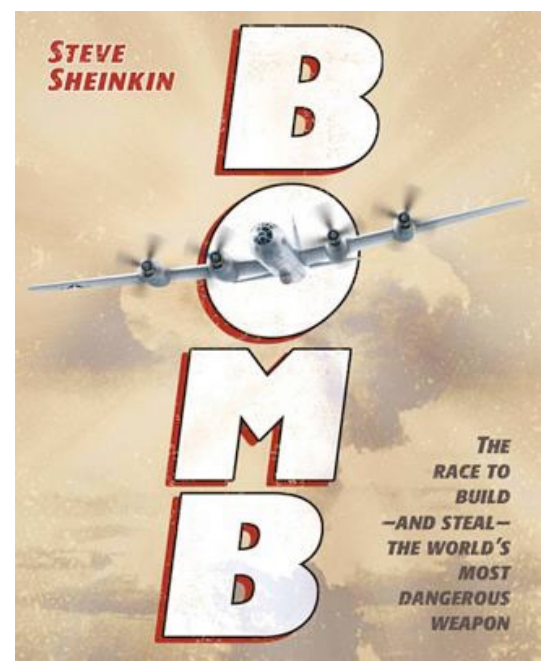

Figure 11.6

Bomb is a combination of history and military science. Bomb: The Race to Build-and Stealthe World's Most Dangerous Weapon written by Steve Sheinkin, 2012, New York, NY: Flash Point. Copyright 2012 by Steve Sheinkin.

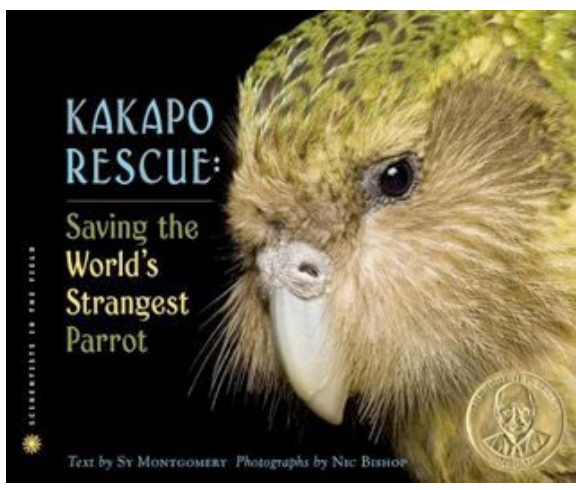

Figure 11.7

You won't forget the images in this book. Kakapo Rescue: Saving the World's Strangest Parrot, written by Sy Montgomery, photographs by Nic Bishop, 2010, New York, NY: Houghton Mifflin Books for Children. Cover art copyright 2010 by Nic Bishop. 


\section{Your Personal Interests and Passions}

I'm sure you expected children's books to cover "school" topics, but what about your personal interests and hobbies? Children's literature spans a range of topics of interest to many different audiences. Are you into sports, drama, religion, charity work? Find children's information books that relate to your personal interests and passions.

- If you like to fish, check out animals of the sea.

- Neighborhood Sharks: Hunting with the Great Whites of California's Farallon Islands by Katherine Roy, 2014, New York, NY: David Macaulay Books (Figure 11.8).

- If you enjoy traveling and learning about different people, places, and times, there are plenty of books for you.

- The Grand Mosque of Paris: A Story of How Muslims Rescued Jews during the Holocaust by Karen Gray Ruelle and Deborah Durland Desaix, 2009, New York, NY: Holiday House (Figure 11.9).

- If you love birdwatching, there are many amazing options.

- Look Up! Bird-Watching in Your Own

Backyard by Annette LeBlanc Cate, 2013,

Somerville, MA: Candlewick (Figure 11.10).

- Are you an artist? Read about museums, different media, art installations, or the artists themselves.

- Drawing from Memory by Allen Say, 2011, New York, NY: Scholastic (Figure 11.11).
Figure 11.8

Roy writes about sharks with great expertise and in simple terms. Neighborhood Sharks: Hunting with the Great Whites of California's Farallon Islands by Katherine Roy, 2014, New York, NY: David Macaulay Books. Copyright 2014 by Katherine Roy.

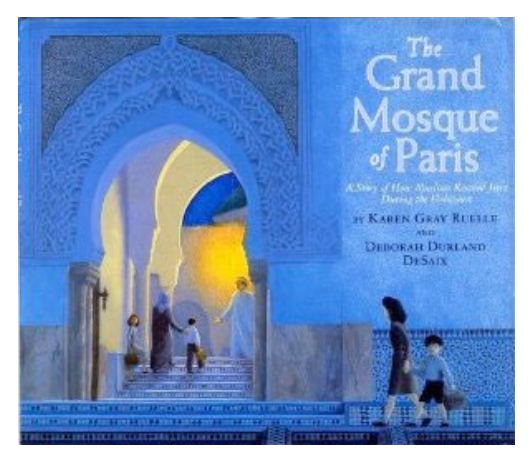

Figure 11.9

If you enjoy learning about different religions and historical sites, read The Grand Mosque of Paris: A Story of How Muslims Rescued Jews during the Holocaust by Karen Gray Ruelle and Deborah Durland Desaix, 2009, New York, NY: Holiday House. Cover art copyright 2009 by Deborah Durland Desaix.

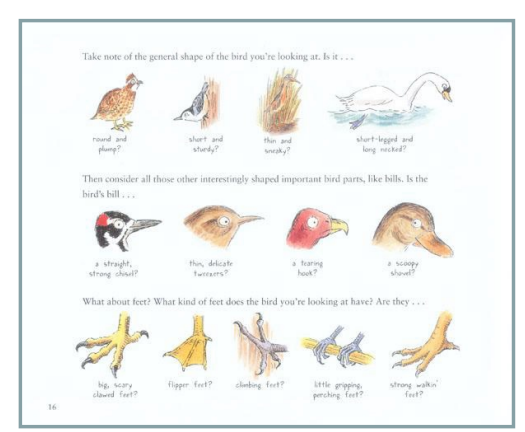

Figure 11.10

Look Up! Is a helpful guide for identifying birds and their features. Look Up! Bird-Watching in Your Own Backyard by Annette LeBlanc Cate, 2013, Somerville, MA: Candlewick. Copyright 2013 by Annette LeBlanc Cate.

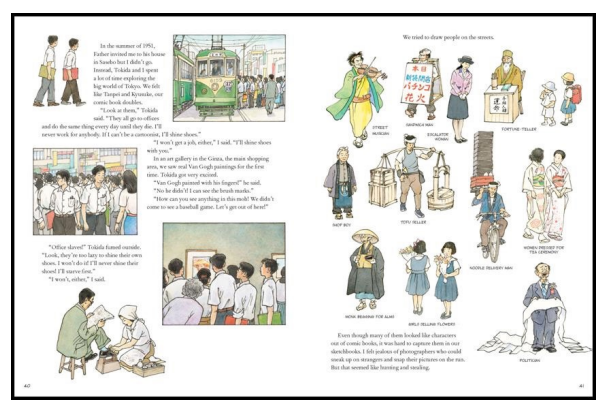

Figure 11.11

Allan Say takes readers on his journey as an illustrator. Drawing from Memory by Allen Say, 2011, New York, NY: Scholastic. Copyright 2011 by Allen Say. 
- Love the cosmos? Look for books about our constantly evolving universe.

\section{- A Black Hole is NOT a Hole by Carolyn Cinami DeCristofano, illustrated by Michael Carroll, 2012, Boston, MA: Charlesbridge (Figure 11.12).}

- Do you scrapbook? Yes, there are kids books about scrapbooking.

- The Scraps Book by Lois Ehlert, 2014, New York, NY: Beach Lane Books (Figure 11.13).

- Love amusement parks? Look for books that share your interest in rollercoasters, cotton candy, and entertainment.

- Mr. Ferris and His Wheel by Kathryn Gibbs Davis and illustrated by Gilbert Ford, 2014, New York, NY: HMH Books for Young Readers (Figure 11.14).

If you think children's books are too simple to add to your knowledge base, think again. Experts across all major fields of study recognize the depth and quality of the content in children's books. Authors and illustrators consult with experts and conduct extensive research to present accurate information. If a book includes detailed information and advanced knowledge, look at the credits for recognition of the consultants, museums, libraries, and organizations who contributed to the book's content.

Now that you've located books that represent your areas of interest and expertise, what do you notice? Did you learn something new?

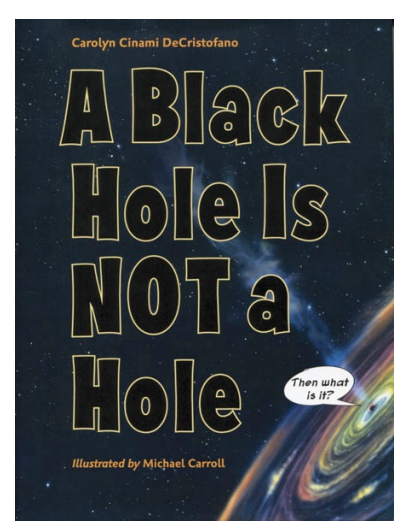

Figure 11.12

Black holes are difficult to understand but this book explains their features with words and images. A Black Hole is NOT a Hole by Carolyn Cinami DeCristofano, illustrated by Michael Carroll, 2012, Boston, MA: Charlesbridge. Cover art copyright 2012 by Michael Carroll.

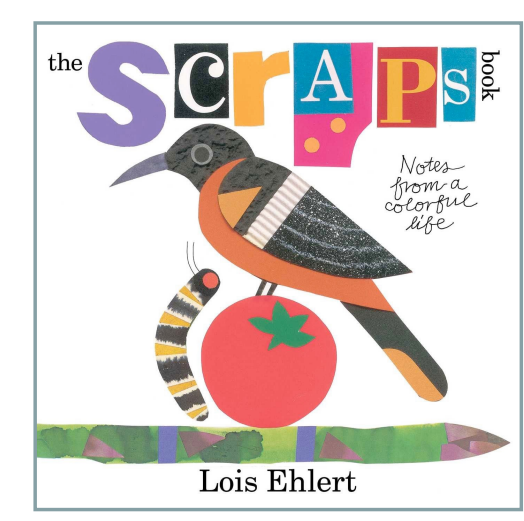

Figure 11.13

Lois Ehlert shares colorful scraps. The Scraps Book by Lois Ehlert, 2014, New York, NY: Beach Lane Books. Copyright 2014 by Lois Ehlert.

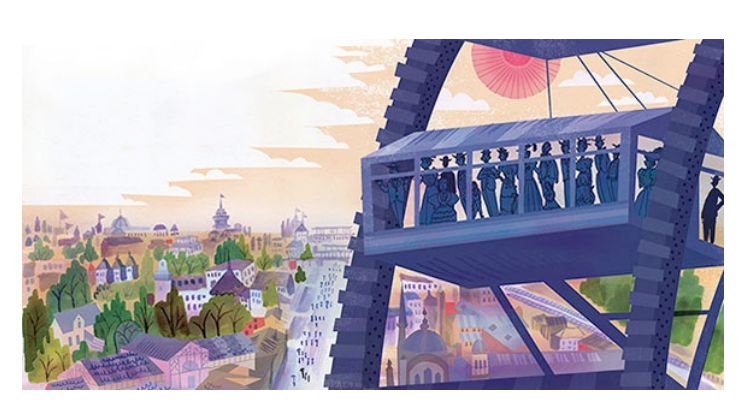

Figure 11.14

Not only does this book provide the history of Mr. Ferris, but the illustrations provide readers with a unique viewing experience of the wheel. Mr. Ferris and His Wheel by Kathryn Gibbs Davis and illustrated by Gilbert Ford, 2014, New York, NY: HMH Books for Young Readers. Illustration copyright 2014 by Gilbert Ford. 
Video 11.1 Survey of Information Books http://www.kaltura.com/tiny/xhgpm

\section{SURVEY OF INFORMATION BOOKS}

\section{WITH JENIFER SCHNEIDER}

\section{THE INSIDE, OUTSIDE, AND UPSIDE DOWNS $\quad$ From Poets and Pop-ups to Princesses \\ OF CHILDREN'S LITERATURE and Porridge}

\section{Limited Topics and Perspectives}

The publishing world has produced fabulous examples of nonfiction books for children. Almost every topic is covered, but not every perspective is explored. For example, I love biographies.

I read celebrity biographies (Figure 11.15),

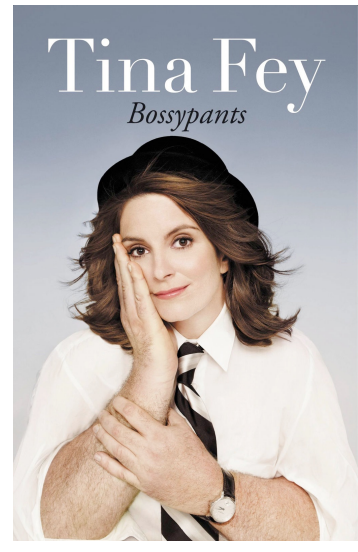

Figure 11.15

Bossypants by Tina Fey, 2014, Boston, MA: Back Bay Books. Copyright 2014 by Tina Fey.

musicians' biographies (Figure 11.16),

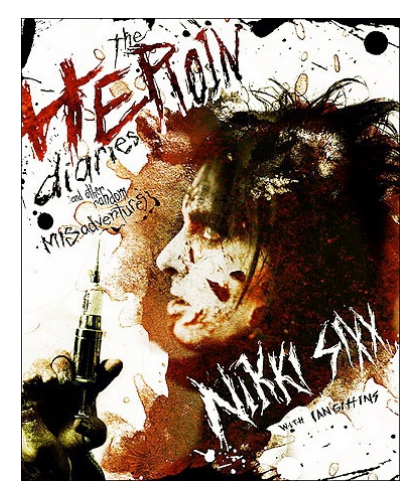

Figure 11.16

Heroin Diaries by Nikki Sixx and lan Gittins, 2007, New York, NY: Pocket Books. Copyright 2007 by Nikki Sixx and lan Gittins. 
athletes' biographies (Figure 11.17),

political biographies (Figure 11.18),

historical biographies (Figure 11.19),

and spiritual biographies (Figure 11.20).

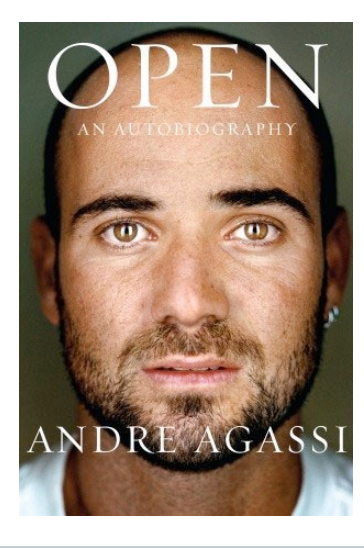

Figure 11.17

Open by Andre Agassi, 2009, New York, NY: Knopf. Copyright 2009 by Andre Agassi.

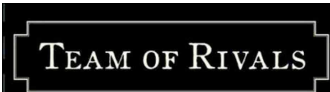

Figure 11.18

Team of Rivals: The Political Genius of Abraham Lincoln by Doris Kearns Goodwin, 2006, New York, NY: Simon \& Schuster. Copyright 2006 by Doris Kearns Goodwin

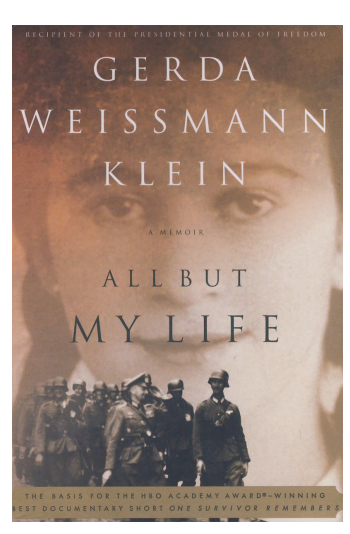

Figure 11.19

All But My Life: A Memoir by Gerda Weissman Klein, 1995, New York, NY: Hill and Wang. Copyright 1995 by Gerda Weissman Klein
The Story of

My Experiments with Truth

Mohandas Karamchand Gandhi

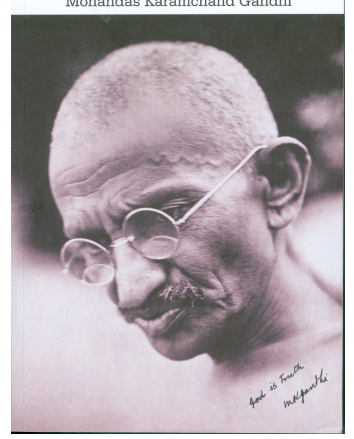

Figure 11.20

The Story of My Experiments with Truth: An Autobiography by Mohandas Karamchand (Mahatma) Gandhi, 2014, Seattle WA: CreateSpace. Copyright 2014 by Mohandas Karamchand (Mahatma) Gandhi.

Of course, these examples are not written for children. Yet, when I examine children's biographies, I see dead people. In fact, I see a lot of dead, white, male people. Where is the children's equivalent of my Tina Fey or Nikki Sixx?

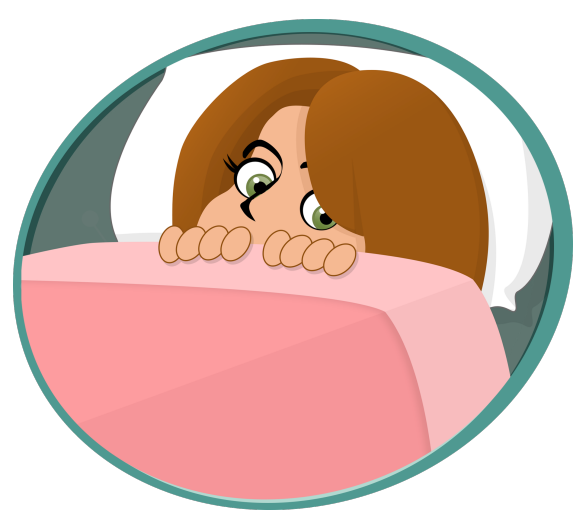


I am not asking for explicit content, but I am calling for information about interesting people beyond the corporate propaganda for the latest movie release or music album. Certainly a series, such as Who Was?/What Was?, attempts to bridge the gap by featuring a wide array of individuals from the present and the past. But how can an individual's unique characteristics come through in a book series with formulaic structures and illustrations that look the same? I want to read a biography on Rev. Lennox Yearwood Jr. and the creation of the Hip Hop Caucus (http://www.hiphopcaucus.org/) written by Jacqueline Woodson and illustrated by Chris Raschka (it doesn't exist, but that's what I want to read). Or how about a book on the environment that traces the work of Adrianna Quintero, executive director of Voces Verdes (http://www.vocesverdes.org/) and senior attorney at the Natural Resources Defense Council. This book doesn't exist either. But I want to read it.

I am not alone in seeing dead people, or archaic ideas, reiterated across texts. In a study about gender roles in children's science biographies, Trevor Owens (2009) determined that Marie Curie and Albert Einstein are the two most frequent subjects of science biographies for children yet they are constructed in gendered ways. He points out that neither of these individuals was from the United States and they are continually portrayed as hating school. He wrote:

Children's books on Curie have changed in emphasis. Now, instead of simply describing Curie's accomplishments without context, children's books have adapted to explain the genderbiased world of science and thus demonstrate the further greatness of those accomplishments. Alongside this transition, books on Einstein have begun to offer a much more sympathetic portrayal of Mileva, both as a wife and in most cases as a physicist. Interestingly, the changes in tone in the Curie books began in the late seventies while the change in portrayal of Mileva did not occur until the mid nineties. Despite the increasingly conscious and explicit treatment of gender relations in such children's books, subtle attitudes towards gender emerge in other contexts, sometimes with much less reformatory potential; in particular, in persistently stereotypical-and gendered-treatments of both Curie's and Einstein's relations to authority in school. (Owens, 2009, p. 937) 
In the world of children's literature, portrayals are still gendered and so are the editor's choices in whose story gets told. For example, by the end of 2015, readers of the Who Was? series could choose from 26 biographies about women (Figure 11.21) and 71 biographies about men (Figure 11.22). In the What Was? series, there were 14 books about topics such as What Was Pompeii? and What Was the Alamo? Of these 14 books, only four books featured a person of color on the cover (The March on Washington, The Underground Railroad (Figure 11.23), The Panama Canal, The First Thanksgiving), and four books featured an image of a woman on the cover (The Underground Railroad, Pompeii, Ellis Island, The Statue of Liberty). If this very popular series is any indication of the status of the field, the field is racist and sexist (and other things that I can't easily see or count). In fact, Thomas Crisp (2015) reviewed the winners of the Orbis Pictus Award for Nonfiction. Using categories of "populations identified frequently as being underrepresented and/or marginalized within children's literature" (p. 244), he found

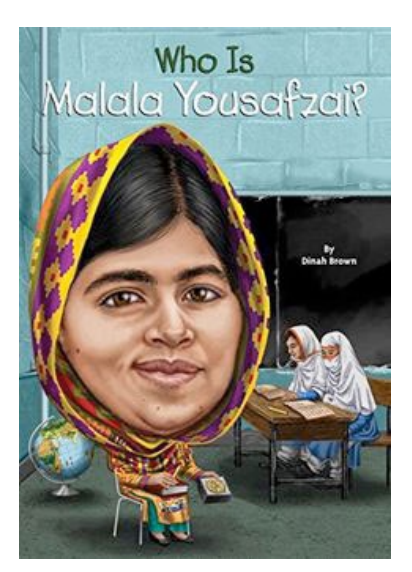

Figure 11.21

The Who Is series publishes biographies of interesting women much less frequently than biographies of men. Who is Malala Yousafzai? By Dinah Brown and illustrated by Andrew Thomson, 2015, New York, NY: Grosset \& Dunlap. Cover art copyright 2015 by Andrew Thomson.

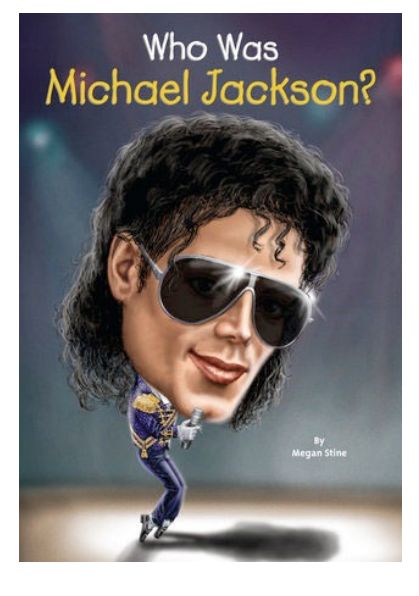

\section{Figure 11.22}

Michael Jackson and Jesus were two of the many male biographies published in the same year. Who was Michael Jackson? By Megan Stine and illustrated by Joseph J.M. Qiu, 2015, New York, NY: Grosset \& Dunlap. Cover art copyright 2015 by Joseph J.M. Qiu.

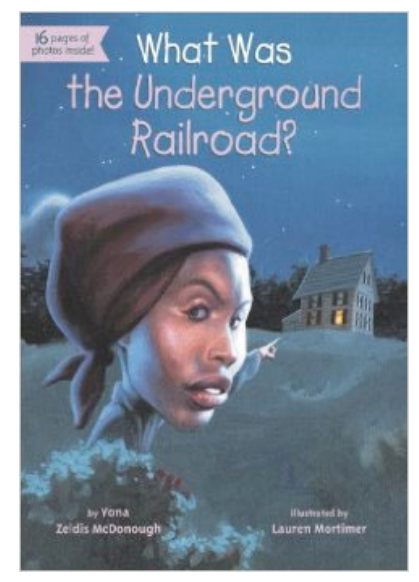

Figure 11.23

What was the Underground Railroad? By Yona Zeldis McDonough and illustrated by Lauren Mortimer and James Bennett, 2013, New York, NY: Grosset \& Dunlap. Cover art copyright 2013 by Lauren Mortimer and James Bennett. deficits in portrayals of sexual identities, religions, ages, and regions of the world. For those who think race, gender, sexual, economic, and social inequality is solved. Think again.

Children are not vacuous. Children need nonfiction books that address their issues and the concerns of their generation-the environment, Internet safety, bullying. All youth, boys and girls, need to read about the women who shaped history and science. We all need to know about important contributions from people of color. 
To explore some of the better examples of contemporary biographies (even though most of the people are still dead), I have selected a range of books highlighting different approaches.

\section{Choose ONE from the following:}

- Amelia and Eleanor Go For a Ride by Pam Munoz Ryan and illustrated by Brian Selznick, 1999, New York, NY: Scholastic (Figure 11.24).

- The Watcher: Jane Goodall's Life with the Chimps by Jeanette Winter, 2011, New York, NY: Schwartz and Wade

(Figure 11.25).

- Harlem's Little Blackbird by Renee Watson, 2012, New York, NY: Random House (Figure 11.26).

\section{- Wilma Unlimited: How Wilma Rudolph} Became the Fastest Woman by Kathleen Krull and illustrated by David Diaz, 2000, New York, NY: HMH Books for Young Readers (Figure 11.27).

- Here Come the Girl Scouts!: The Amazing All True Story of Juliette

\section{'Daisy' Gordon Low and Her Great}

Adventure by Shana Corey and illustrated by Hadley Hooper, 2012, New York, NY:

Scholastic (Figure 11.28).

\section{- Almost Astronauts: 13 Women Who}

Dared to Dream written by Tanya Lee

Stone, 2009, Somerville, MA: Candlewick

(Figure 11.29).

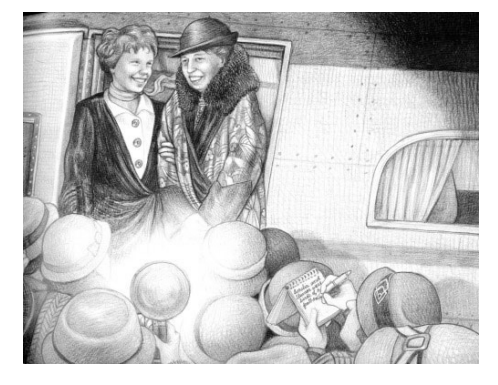

Figure 11.24

On their own, Amelia and Eleanor are immensely important. Together, they are unstoppable trailblazers. Amelia and Eleanor Go For a Ride by Pam Munoz Ryan and illustrated by Brian Selznick, 1999, New York, NY: Scholastic. Cover art copyright 1999 by Brian Selznick.

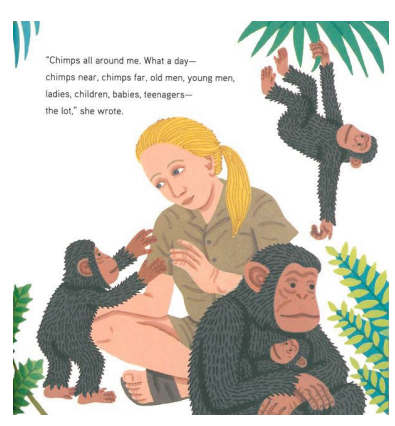

Figure 11.25

Jane Goodall is an amazing scientist and conservationist. The Watcher: Jane Goodall's Life with the Chimps by Jeanette Winter, 2011, New York, NY: Schwartz and Wade.Copyright 2011 by Jeanette Winter.

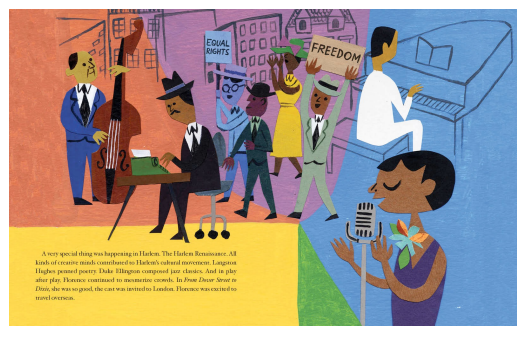

Figure 11.26

I like biographies of lesser known people such as Harlem's Little Blackbird by Renee Watson, 2012, New York, NY: Random House. Copyright 2012 by Renee Watson.

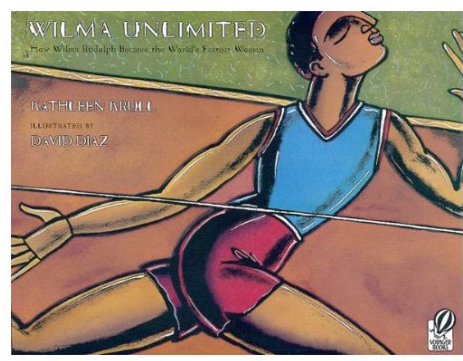

Figure 11.27

From braces to winning races. Women are sports heroes too. Wilma Unlimited: How Wilma Rudolph Became the Fastest Woman by Kathleen Krull and illustrated by David Diaz, 2000, New York, NY: HMH Books for Young Readers. Cover art copyright 2000 by David Diaz.

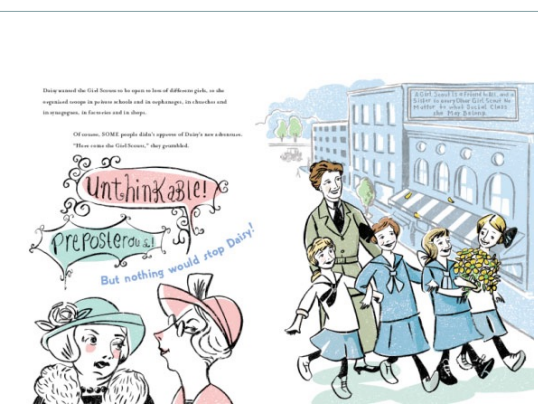

Figure 11.28

How many people know about the origins of the girl scouts? Here Come the Girl Scouts!: The Amazing All True Story of Juliette 'Daisy' Gordon Low and Her Great Adventure by Shana Corey and illustrated by Hadley Hooper, 2012, New York, NY: Scholastic. Cover art copyright 2012 by Hadley Hooper.

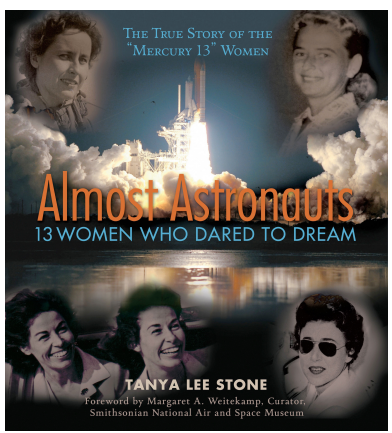

Figure 11.29

This collection of stories features brave women who changed the space industry. Almost Astronauts: 13 Women Who Dared to Dream written by Tanya Lee Stone, 2009, Somerville, MA: Candlewick. Cover art copyright 2009 by Tanya Lee Stone. 


\section{Choose ONE from the following:}

- Nelson Mandela by Kadir Nelson, 2013, New York, NY: Katherine Tegen Books

(Figure 11.30).

- Hanging Off Jefferson's Nose: Growing Up on Mount Rushmore by Tina Coury and illustrated by Sally Wern Comport, 2012, New York, NY: Dial (Figure 11.31).

- Jim Henson: The Guy Who Played with Puppets by Kathleen Krull and illustrated by Steve Johnson and Lou Fancher, 2011, New York, NY: Random House (Figure 11.32).

- Lou Gehrig by David A. Adler and illustrated by Terry Widener, 2001, New York, NY: HMH Books for Young Readers (Figure 11.33).

\section{- It Jes' Happened: When Bill Traylor}

Started to Draw by Don Tate and illustrated by R. Gregory Christie, 2012, New York, NY: Lee \& Low (Figure 11.34).

- Freedom Riders: John Lewis and Jim Zwerg on the Front Lines of the Civil Rights Movement by Ann Bausum, 2005, Washington, D.C.: National Geographic Books (Figure 11.35).

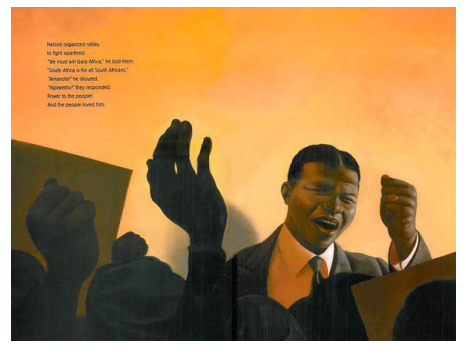

Figure 11.30

He never lost hope. Nelson Mandela by Kadir Nelson, 2013, New York, NY: Katherine Tegen Books. Copyright 2013 by Kadir Nelson.

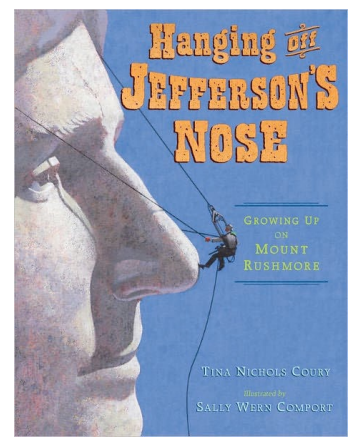

Figure 11.31

I've never thought about the creation of Mount Rushmore; just the final result. Here is the inside story. Hanging Off Jefferson's Nose: Growing Up on Mount Rushmore by Tina Coury and illustrated by Sally Wern Comport, 2012, New York, NY: Dial. Cover art copyright 2012 by Sally Wern Comport.

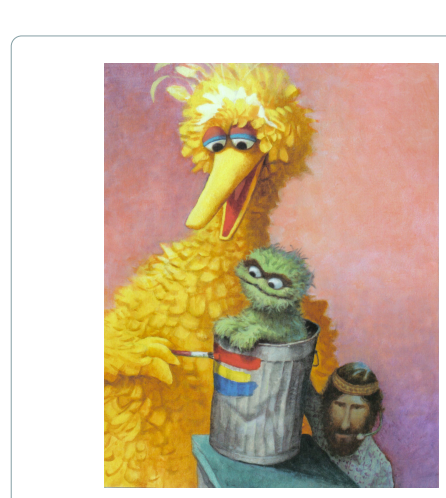

Figure 11.32

He created characters that millions of people have loved for decades. Jim Henson: The Guy Who Played with Puppets by Kathleen Krull and illustrated by Steve Johnson and Lou Fancher, 2011, New York, NY: Random House. Cover art copyright 2011 by Steve Johnson.

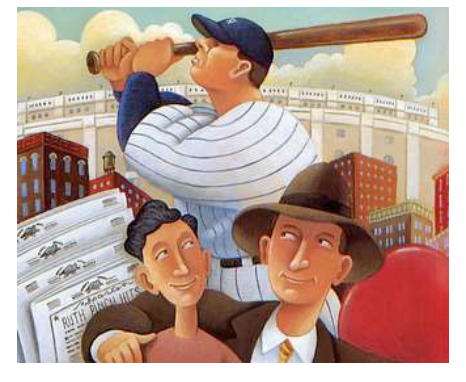

Figure 11.33

David Adler tells Lou Gehrig's story from his childhood to his becoming the luckiest man on the face of the Earth. Lou Gehrig by David A. Adler and illustrated by Terry Widener, 2001, New York, NY: HMH Books for Young Readers. Cover art copyright 2001 by Terry Widener.

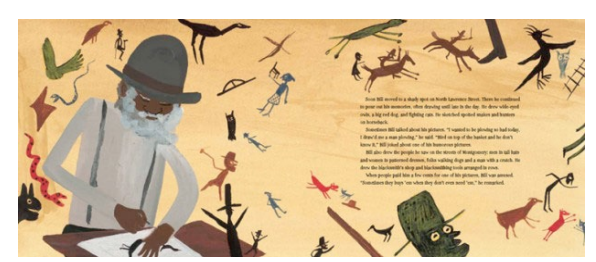

Figure 11.34

Here is a story of untapped talent. It Jes' Happened: When Bill Traylor Started to Draw by Don Tate and illustrated by R. Gregory Christie, 2012, New York, NY: Lee \& Low. Cover art copyright 2012 by R. Gregory Christie.

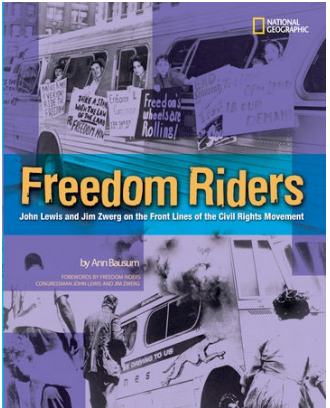

Figure 11.35

The Freedom Riders exhibited extraordinary bravery and changed the world. Freedom Riders: John Lewis and Jim Zwerg on the Front Lines of the Civil Rights

Movement by Ann Bausum, 2005, Washington, D.C.: National Geographic Books. Copyright 2005 by Ann Bausum. 
Here are some questions to guide your thinking and analysis:

- How are the individuals portrayed?

- Pay attention to the language in the two books you selected. Do you notice differences and similarities in how the main character is described?

- Compare the content of both books. Do you notice any differences or similarities in the topics covered? What events are highlighted?

- What personal strengths or challenges are featured?

- How did the illustrations affect your reading?

- How did the illustrator's choices impact your view and understanding of each person?

It's also interesting to compare different approaches to the same person/topic.

Here are a few to examine:

I Am Malala: How One Girl Stood Up for Education and Changed the World by

Malala Yousafzai and Patricia Mccormick

Who is Malala Yousafzai by Dinah Brown and Andrew Thomson

Marcel Marceau: Master of Mime by Gloria Spielman and Manon Gauthier

Monsieur Marceau: Actor Without Words by Leda Schubert and Gerard DuBois

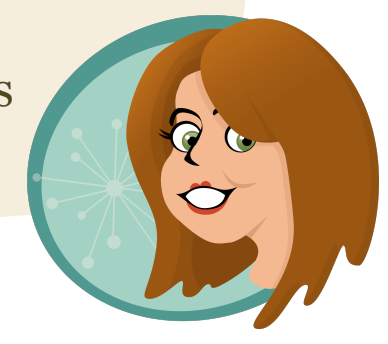

Do biographies for children/youth have to be about a famous person's childhood? No. My daughter watched an episode of Cosmos in which Clair Patterson was featured (http:// natgeotv.com/uk/cosmos-a-spacetime-odyssey/videos). Clair Patterson was the man who fought big oil and big research to expose the high concentrations of lead in gasoline and its impact on the environment. Cosmos did not highlight Clair's childhood; they told the story of his work, his science, and the politics of truth. Based on their portrayal, my daughter selected Clair Patterson as the person for her National History Day project. 
Do biographies for children/youth have to censor the information and focus on positive experiences? No. Contemporary biographies are showing signs of wrestling with difficult issues and tragic experiences. Many books have been written about the Holocaust. Fewer books have been written about history since World War II. Shouldn't children and youth know more about Vietnam, Watergate, or 9/11? Perhaps these topics are too big and complicated? Maybe they are too new? Well, take a look at Hitler Youth: Growing Up in Hitler's Shadow by Susan Campbell Bartoletti (2005) and you will see an example of how to focus on parts of a complex situation.

Do biographies and nonfiction texts have to focus on serious issues? No. Youth like to read about topics that are relevant to their lives. Sometimes kids want to know who invented Cheetos. Heck, I want to know who invented Cheetos. We know who invented the lightbulb, but who were the people (women and men) who invented the smartphone the iPad, Space Invaders, Super Mario, or Call of Duty?

Biographies and other forms of narrative nonfiction shed light on the past and present. They help us understand events and put them in context of the time. If we all ask for, buy, and check out more interesting biographies and nonfiction books, then more interesting choices will come (Video 11.2).

Video 11.2 Survey of Biography Books http://www.kaltura.com/tiny/njvw5

\section{SURVEY OF BIOGRAPHY BOOKS}

\section{WITH JENIFER SCHNEIDER}




\section{Expertise and Interesting Writing}

Nonfiction writers conduct extensive research and consult with experts, bridging the gap between a field of study and the intended audience of children. In other words, the nonfiction writer is an information translator, recasting details in a different way. Of course, there are always bad examples of nonfiction. But, you might also be surprised by the depth and breadth of what is available.

\section{Author Expertise}

Many writers of nonfiction for children have professional backgrounds and training in the area in which they write. Many of them also have careers in teaching and working with children. Below, I’ve highlighted a few individuals.

- Seymour Simon studied Science at the City College of New York. He has a Masters in Comparative Psychology, which is the study of Animal Behavior. He taught middle school science for over 20 years, developing his knowledge of what interests youth and the ways in which children learn about the world (http://www.seymoursimon.com/index.php/ about seymour simon/faq/)

- David A. Adler graduated from Queens College with a BA in economics and education with licenses to teach mathematics and history. He was a New York City mathematics teacher for nine years. While teaching he earned his MBA in marketing and began a $\mathrm{PhD}$ in marketing when he was inspired to write books (http://www.davidaadler.com/bio.htm).

- Susan Campbell Bertoletti has a Bachelors in English and Secondary Education from Marywood University in Scranton, PA. She taught Eighth Grade English (composition, grammar, and literature) for 18 years. She has a Masters in English from the University of Scranton where she also taught courses in composition. She earned a Ph.D. in English from Binghamton University, State University of New York with a creative nonfiction dissertation (Black Potatoes: The Story of the Great Irish Famine, 1845 to 1850. (Published by Houghton Mifflin). She taught courses in creative writing at the college level (http://www.scbartoletti.com/downloads/CV 2010.pdf).

- Vicki Cobb graduated from Barnard College with a major in zoology and a Master's degree in Secondary Science Education. After an early career as a laboratory researcher, she eventually worked as a science teacher, and then she became a full-time writer of science books for children (http://www.vickicobb.com/aboutvicki.html). 
I selected these four award-winning, nonfiction writers because I personally value their work. I am especially impressed with their depth of research, their perspectives on the topics on which they write, their abilities to write for the targeted age level, and their literary styles. As these selected individuals demonstrate, nonfiction writers have personal expertise in the subjects about which they write, and if they don't have formal training, they have the education and advanced skills necessary to conduct research. As Seymour Simon wrote,

Whenever I want to write about a subject, I need to study. I start by looking at research that other people have done. What experiments have they run? What animals have they observed? By studying all the work that others have already done, I learn about the subjects that I write about in my books. As the great scientist Sir Isaac Newton once wrote, 'If I have seen further than others, it is because I have stood on the shoulders of giants' (http://www.seymoursimon.com/ index.php/about seymour simon/faq/).

It is not a coincidence that each of these successful writers was also a teacher. I didn't select these individuals because they were teachers, but I believe their extraordinary success in writing for children is a direct result of years of talking with, listening to, and learning from children and youth. As teachers, they learned how to help students access complex disciplinary information by breaking down concepts, modeling ways of thinking, and using writing across the disciplines as a method of communication. They also honor children as intelligent, thoughtful individuals who appreciate accurate information that is written in respectful and interesting ways. 


\section{Language Features and Readability}

There is an art to writing interesting nonfiction. When presenting information, an author needs to engage the reader while also explaining the content with detail and accuracy. Some authors err on the side of entertainment. For example, when describing how blood flows through the body, an author might animate the blood cells and portray them as talking to one another (Figure 11.36).

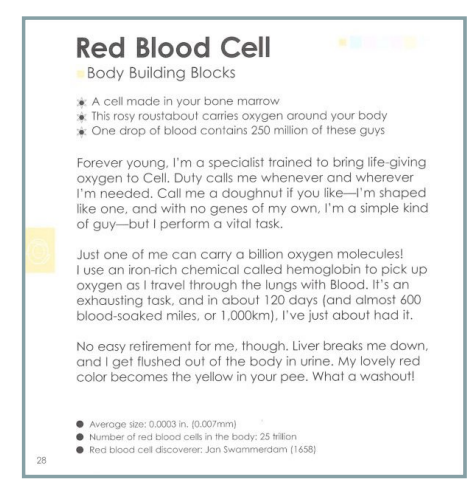

\section{Figure 11.36}

Fictional storytelling techniques are frequently used in Basher books. Human Body: A Book with Guts! By Dan Green and Simon Basher and illustrated by Simon Basher, 2011, New York, NY: Kingfisher. Text copyright 2011 by Dan Green and Simon Basher.

Although anthropomorphism and personification appear to add character and interest to nonfiction topics, they are authorial techniques for fictional storytelling. If the purpose of the text is to present information, then the author should use effective nonfiction techniques while maintaining accuracy and authentic information.

In Chapter 5, I combined criteria from national nonfiction awards to guide you in the selection of quality nonfiction.

Criteria to evaluate information books:

- Interesting and timely subject matter

- Excellent, engaging, and distinctive use of language.

- Excellent, engaging, and distinctive use of visuals in illustrated texts (for picturebooks see below).

- Appropriate organization with clear sequencing and logical development

- Thorough documentation and author's qualifications

- Clear, accurate, and stimulating presentation of facts, concepts, and ideas.

- Appropriate style of presentation for subject and for intended audience.

- Supportive features (index, table of contents, maps, timelines, etc).

- Respectful and of interest to intended audience.

Anthropomorphism is the attribution of human form or other characteristics to beings other than humans, particularly deities and animals. People attribute human-like mental states, for example, to God and non-human animals.

Personification is the related attribution of human form and characteristics to

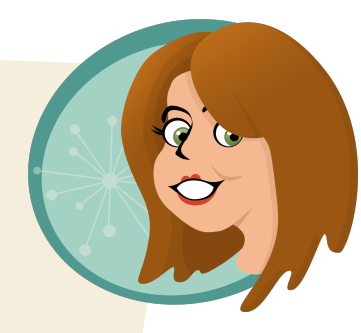
abstract concepts such as nations and natural forces such as the seasons and the weather.

Both anthropomorphism and personification have ancient roots as storytelling and artistic devices. Most cultures have traditional fables with anthropomorphized animals as characters. 
Some information should be narrated. In these instances, there is a dual purpose: to present information and narrate a series of events. Seymour Simon wrote, "I write stories for children that happen to be non-fiction. I don't write textbooks, or encyclopedias, I'm telling stories" (http://www.seymoursimon.com/index.php/about_seymour_simon/faq/). In the technical sense, Seymour Simon does not tell stories (plot, setting, characters), but he does use narration and argumentation to present information.

The content of nonfiction texts is expansive. With so much to cover, authors may use different formats and text structures to highlight information, isolate important ideas, and make connections across the text. The author's use of text features can help the reader locate information and make sense of the content. Text features include headings and subheadings, captions, diagrams, labels, text boxes, images, indexes, glossaries, and key words (Figure 11.37). Although these features are used in children's books, many readers skip over text boxes, diagrams and other features that assist comprehension. Children, youth, and many adults need guidance to understand how the text features work to help them understand the information in a book.

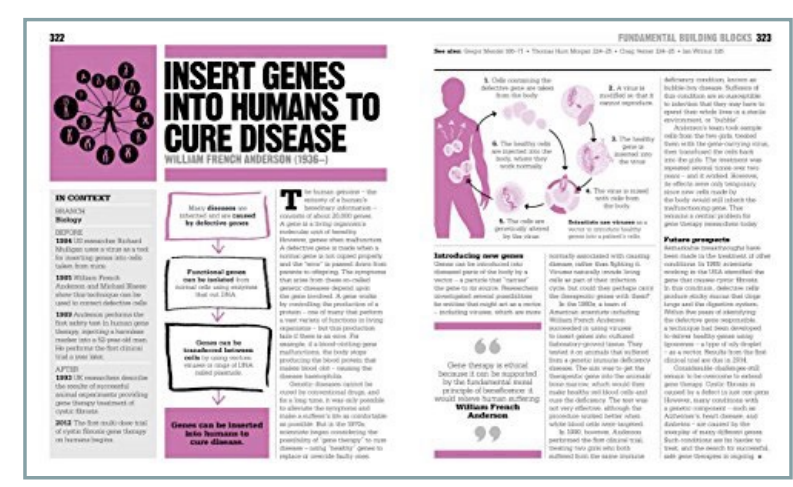

Figure 11.37

Headings and subheadings, captions, diagrams, labels, text boxes, images, indexes, glossaries, and key words help readers understand The Science Book: Big Ideas Simply Explained by Dan Green, 2014, Washington, D.C.: DK Books. Excerpt copyright 2014 by Dan Green.

Reading aloud nonfiction text is extremely important. Children need to develop an ear for nonfiction as well as for story and poetry.

Jennifer Wharton, a blogger for the Children's and Young Adult Bloggers' Literary Awards has compiled a list of nonfiction read aloud books: http://www.cybils.com/2015/02/list-fun-read-aloud-non-fiction.html.

Many public librarians have developed helpful lists and suggestions for nonfiction reading: http://www.aadl.org/user/lists/61527

Pinterest also includes several lists for nonfiction read alouds:

https://www.goodreads.com/shelf/show/non-fiction-read-aloud 
Children and youth enjoy reading nonfiction books, but they are often dissuaded by teachers who tend to prefer fictional texts. Children typically receive very little time to read nonfiction in school. In fact, in 2000, Nell Duke made the literacy world stand up and take notice of the paucity of attention given to nonfiction texts. In a study of 20 first-grade classrooms, Duke found that children spent an average of 3.6 minutes per day with informational texts during classroom written language activities. This study initiated a series of follow-up studies and additional attention to the role of nonfiction texts in schools. More recently, the Common Core State Standards (National Association of Governors, 2014) have emphasized the reading of nonfiction text, given that most college and career paths require extensive nonfiction reading.

In addition to more reading time, teachers, librarians, and parents should read aloud nonfiction texts. Reading aloud gives the reader an "ear" for nonfiction and explicit instruction provides direct information about the strategies to use (Video 11.3).

Video 11.3 Information Book Read Aloud http://www.kaltura.com/tiny/sikgx

\section{READING INFORMATION BOOKS}

WITH JENIFER SCHNEIDER

\section{THE INSIDE, OUTSIDE, AND UPSIDE DOWNS | From Poets and Pop-ups to Princesses OF CHILDREN'S LITERATURE}


If you select the right book, the reading is easy. If not, the reading is snoozy. Pay attention to the language choices in the following excerpts from different books about wind.

\section{Face The Wind by Vicki Cobb, illustrated by Julia Gorton (2003)}

Ever face a strong wind?

Your hair blows away from your face.

You could lose your hat.

And if the wind is blowing hard enough, you may even have to walk at a slant.

You can't see this force that's pushing you. But you can feel it. And you can see what wind does to other things.

It makes dust swirl in a circle.

It makes flags stick out straight and flutter.

Can you name some things you see wind do?

Go outside and watch.

Leaves on trees shake.

A kite stays in the sky...

Vicki Cobb received a Sibert Honor Award for this book. I feel it is an outstanding example of nonfiction writing. The reader is engaged. He or she must make references to windy experiences in his or her own life. This is a classic example of showing the reader, not telling the reader. Instead of saying, "wind has energy-here's the evidence," Vicki Cobb showed us through examples.

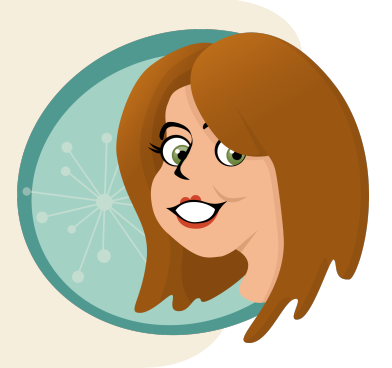

\section{Wind by Marion Dane Bauer, illustrated by John Wallace (2003)}

The earth we live on is a spinning ball.

When the earth spins, the air around it moves too.

When air moves we call it "wind."

As the sun heats the air, the air grows lighter. Light air rises.

Cool air is heavy. It falls...

Marion Dane Bauer's book is more simplistic than Cobb's, but not as engaging. The concepts are presented as statements without any explanation of the science. Why does hot air get lighter? Why does hot air rise?

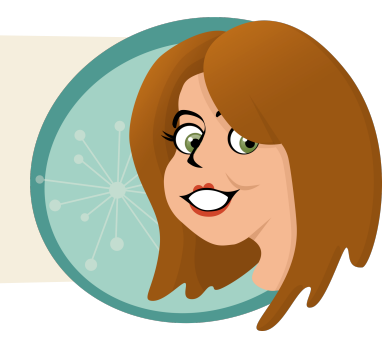




\section{Wind Energy Engineering by Pramod Jain (2010, p. 9-10)}

The energy of wind has been exploited for thousands of years. The oldest applications of wind energy include extracting water from wells, making flour out of grain, and other agricultural applications. In recent times, the use of wind energy has evolved to, primarily, generation of electricity (p. 1) ... The kinetic energy contained in wind is:

$\mathrm{E}=1 / 2 \mathrm{mv} 2$ where $\mathrm{m}$ is mass and $\mathrm{v}$ is speed; units of energy are $\mathrm{kg} \mathrm{m} 2 / \mathrm{s} 2=$ Joule.

The mass (m) from which energy is extracted is the mass contained in the volume of air that will flow through the rotor.

Pramod Jain wrote this book for audiences interested in higher levels of science content. The information is straightforward and easy to understand. Jain also uses real life examples and practical applications for the science. However, he is not engaging with the audience as much as he is presenting the information.

\section{The Importance of Illustration}

As you might imagine, illustrations play a central role in nonfiction texts for youth. Even the most dense nonfiction narratives will include some photographs and illustrations. For example, look at the examples of the books about wind. In each book, the illustrations play a different role.

In Vicki Cobb's book, the images help the reader think about the words she wrote. They guide the reader to pay attention to the examples in their own world (Figure 11.38).

In Marion Dane Bauer's book, the images add interest to the text, but they do not necessarily add informational content (Figure 11.39).
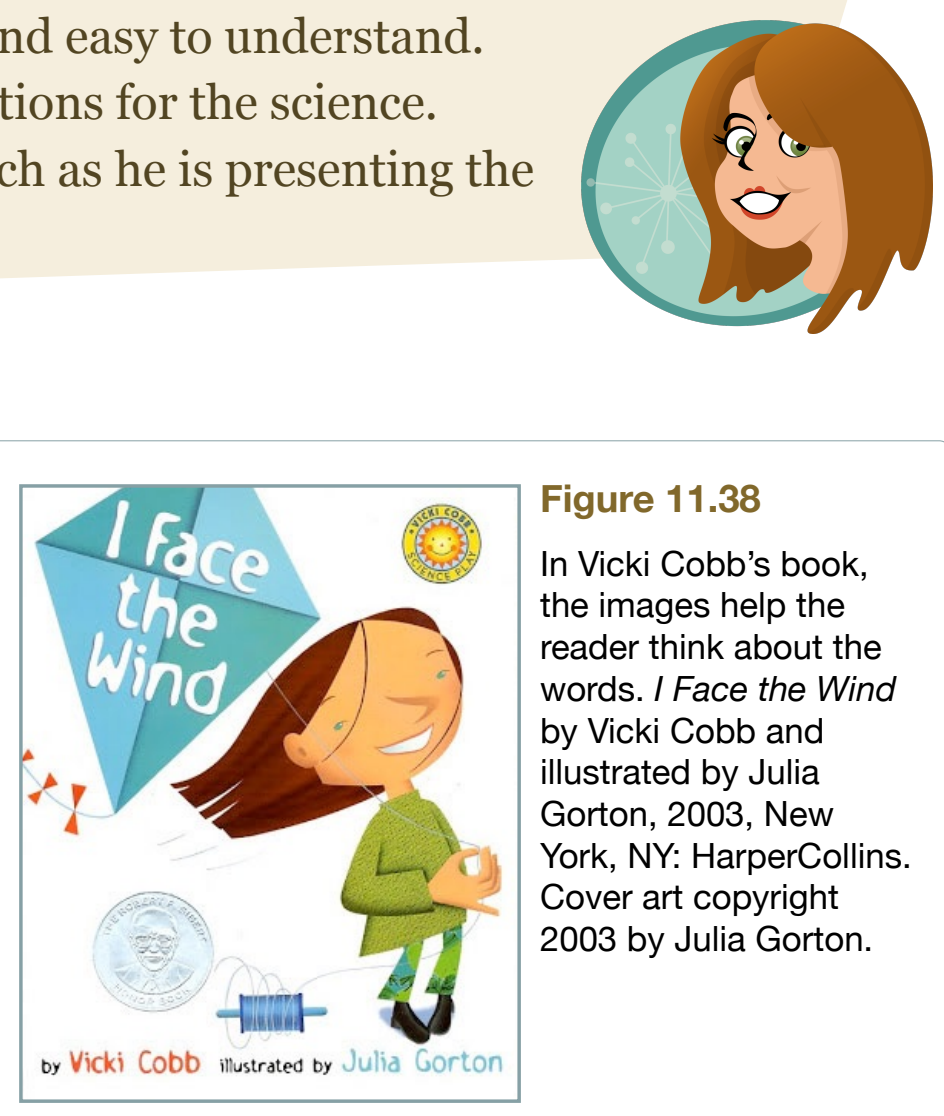

Figure 11.38

In Vicki Cobb's book, the images help the reader think about the words. I Face the Wind by Vicki Cobb and illustrated by Julia Gorton, 2003, New York, NY: HarperCollins. Cover art copyright 2003 by Julia Gorton.

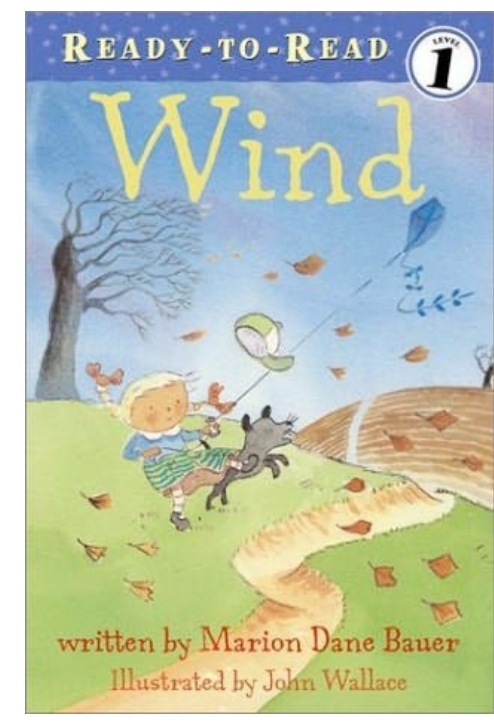

Figure 11.39

In Marion Dane Bauer's book, the images add interest to the text. Wind by Marion Dane Bauer and illustrated by John Wallace, 2003, New York, NY: Simon Spotlight. Cover art copyright 2003 by John Wallace. 
In Pramod Jain's book, the images are selected to illustrate concepts that require visualization. For example, how is a turbine constructed? In this case, it's easier to show the visual than describe or inform through text. The illustrations take the place of needless technical writing (Figure 11.40).

Unlike a young adult novel, the purpose of a nonfiction text is to share information. Therefore, photographs, drawings, illustrations and other forms of media are

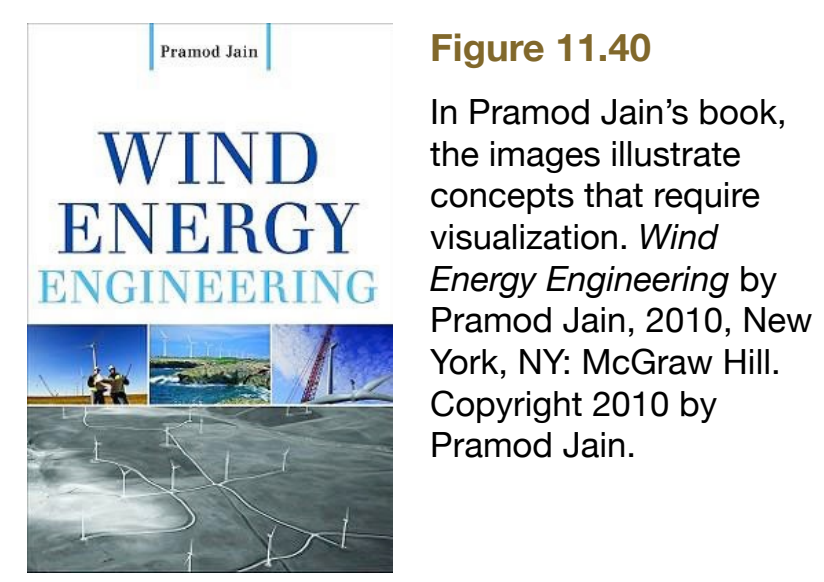
useful in presenting the information across various modes.

With informational texts, the same standards for artistic quality apply as for any picture book. Illustrated nonfictional texts are similar to, but different from, illustrated fiction.

If the information is presented in the form of a picture book, I use the following criteria from the Caldecott Medal (ALA) to determine the book's quality.

- Excellence of execution in the artistic technique employed;

- Excellence of pictorial interpretation of theme or concept;

- Appropriateness of style of illustration to the theme or concept;

- Delineation of information through the pictures;

- Excellence of presentation in recognition of the intended audience.

\section{DETERMINING THE COMMUNICATIVE PURPOSE OF TEXT AND ILLUSTRATION}




\section{Looking Past Dead Presidents and the Same Ol' Inventors}

Good examples of nonfiction are written about all aspects of disciplinary content-from the microscopic (atom) to the enormous (universe). Good examples of nonfiction are also written about all kinds of people who have contributed to society across time periods and across the globe. Modern, effective writers and illustrators accurately inform readers through beautiful language and detailed illustrations. But there is work to do. Nonfiction books continue to feature a lot of dead white people involved in lifeless events that have little relevance to youth. We need to choose nonfiction books carefully and demand excellence and diversity in the coverage of topics for children.

For more on this topic, here is an opinion on the topic: http:// www.buzzfeed.com/hannahjewell/inventions-by-women-thatchanged-the-world\#.lmBWaw2Nx. Caution, this article contains offensive language.

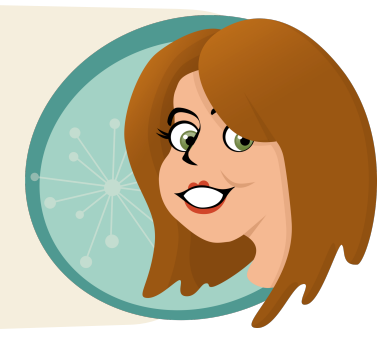

